\title{
The Effect of Work Motivation Dimension on the Performance of Employees of PT. Gapura Angkasa of Minangkabau International Airport Padang
}

\author{
Sutiyem ${ }^{1}$, Muthia Roza Linda ${ }^{2}$, Suhery ${ }^{3}$, Puspa Leni ${ }^{4}$, Dessy Trismiyanti ${ }^{5}$ \\ ${ }^{1}$ STIE Perdagangan, Padang and Indonesia, $\square$ (e-mail) iyeksurti@yahoo.com \\ ${ }^{2}$ Universitas Negeri Padang , Padang and Indonesia, $\square$ (e-mail) muthia rozalinda@yahoo.com \\ ${ }^{3}$ STIE Perdagangan , Padang and Indonesia, $\square$ (e-mail) suheriasia@gmail.com \\ ${ }^{4}$ STIE Perdagangan , Padang and Indonesia, $\square$ (e-mail) puspaleni@gmail.com \\ ${ }^{5}$ STIE Perdagangan , Padang and Indonesia, $\square$ (e-mail) dessytrismiyanti@ymail.com
}

\begin{abstract}
The objective of this study is to analyze: 1) the effect of the need for achievement on the employees' performance; 2) the effect of the need for affiliation on the employees' performance; and 3) the effect of the need for power on the employees' performance. This study is a causative research which objective is to see to what extent that the independent variables affect the dependent variable. The research population is the employees of PT. Gapura Angkasa of Minangkabau International Airport Padang. The study used census sampling technique and employed total respondent as the sample with the total sample of 127 respondents. Out of 127 distributed questionnaires, only 116 questionnaires were returned to the researchers. For data analysis technique, the study used multiple linear regressions, using t-test and coefficient of determination $\left(\mathrm{R}^{2}\right)$ assisted with the SPSS software version 24 . The research results conclude that: 1) the need for achievement has a significant effect on the employees' performance; 2) the need for affiliation has no significant effect on the employees' performance; and 3) the need for power has a significant effect on the employees' performance. The value of adjusted $R$ square is equal to 0,675 , which means that the independent variables of this study collectively affect the dependent variable up to $67,51 \%$.
\end{abstract}

Keywords: Performance, the need for achievement, the need for affiliation, the need for power

\section{Introduction}

Employee performance is the level of achievement of each employee within a company. Employee performance has become an element for achieving a satisfactory company performance. Mangkunegara (2009: 67) states that performance is a work result in which the quality and quantity of the task performed by an employee is in accordance with the assigned responsibilities. Performance is a work result that is generated by an employee or a display of tangible behaviors that are in accordance with the assigned responsibilities.

Employee performance is necessary to be used by an organization as a benchmark to determine the level of effectiveness of an employee's work progress. According to Griffin (2002: 254), performance is "a formal evaluation to determine the effectiveness of employment of an employee". Employee performance is a very important aspect of employees and companies. The factors that affect the performance should be a concern for the company and, therefore, have to be improved.

In general, performance is the activities that employees perform or do not perform, that affect the extent to which the employees will contribute toward the agency or organization, such as the quality of service being served. The organization's success or failure is influenced by the employees' individual and collective performance. A better employees' performance will result in a better 
organizational performance. Based on the various definitions of performance, it is concluded that the performance is a work result achieved by a person or a group of people within an organization according to their authority and responsibility in achieving the organizational goals.

According to Dessler (2010: 329), the indicators of employee performance include:

1. Work Quality, which is the accuracy, neatness, and the precision of a job.

2. Productivity, which is how much work, is generated within a certain period of time.

3. Knowledge about the Job, which includes knowledge, information, and skills owned by employees to assist their work.

4. Reliability: a reliable and capable individual who have the capabilities to accomplish his tasks as expected.

5. Availability: a level in which an employee is on-time and able to manage his time for breaks and overall attendance records.

6. Responsibility: the employees' ability to complete the job according to assigned responsibilities given by the company.

According to Mangkunegara (2009: 67), one factor that affects the performance achievement is motivation. Motivation is the driving force of someone's activities to achieve a particular goal and it involves various capabilities that one has. Motivation is a set of attitudes and values that affect an individual to achieve specific things according to his goals (Rivai \& Sagala, 2009: 837). Marjani in Hudiwinarsih (2005: 218) proposed that there is a positive relationship between motivation and employees' performance. The result of the study found that the condition of high work motivation of an employee was associated with the trend of a relatively high level of employees' performance. Employees, who are highly motivated, will attempt to perform as closely as possible to the goals set by the company.

According to Sunyoto (2015), the purpose of providing motivation are: to encourage employees' passion and enthusiasm, to improves employees' morale and job satisfaction, to increases employees' productivity, to maintain the employees' loyalty and stability, to increase discipline and reduce employees' absenteeism, to create a good atmosphere and working relationship, to increase employees' participation, to improve employees' welfare, and to enhance employees' sense of responsibility.

McClelland in Mangkunegara (2009: 103) states that one's productivity is affected by the "mental virus" inside him. A mental virus is a mental condition that drives a person to achieve maximum results. The mental virus is referred to as the needs for achievement, the needs for power, and the needs for affiliation.

1. The need for achievement. According to the Kamus Besar Bahasa Indonesia Dictionary, achievement is the result of what has been achieved. The achievement could be accomplished by using an intellectual, spiritual, and emotional ability, as well as self-persistency towards every aspect of life situations. The need for achievement will encourage someone to excel in any condition as long as the target to be achieved is realistic and the opportunity to obtain it arises, and that one is creative enough. The need for achievement that is formulated and established due to related behaviors is a result of a conflict between expectation to succeed and the fear to fail. The tendency for approach and avoidance results in the needs for achievement, expectations toward success and failure, and the value of incentive derived from success and failure.

2. The need for power. A power is an individual or a group's ability to affect the behavior of other people to behave according to his/their desire. A person who has a high level of need for power tends to behave more firmly. Veroff in Nindyati (2014) defines that the purpose of the need for power is to influence and seek improvement as a part of the objectives of behavior that derives from the needs for achievement.

3. The need for affiliation. An affiliation is a form of social contacts that create a relationship or network. Someone who has needs like this will have the motivation to make friends, to be tolerant 
and cooperative instead of the motivation to compete in the organization. McClelland in Nindyati (2014) explains that individuals with high needs for affiliation tend to be able to maintain good social relationships and are not comfortable in competitive conditions. They are comfortable with norms and expectations and in jobs that require teamwork.

PT. Gapura Angkasa of Minangkabau International Airport Padang is a company that provides support services for aviation and conducts services for underground support activities in the area of West Sumatra, Indonesia. The rapid growth of Indonesia's airline industry results in a higher stake to overcome business challenges. There are several factors that determine the success of a company in achieving its objective; one of which is the support of human resources in the form of highly motivated employees.

Based on the data obtained from January to June 2016 on the employees of PT Gapura Angkasa of Minangkabau International Airport Padang, it was found that there have been occurrences or cases of non-compliance procedures in work performance, ranging from the Loading Unloading unit to the Cargo unit, where 276 cases were recorded. The number continued to increase reaching up to 409 cases until the end of June 2016. This was due to the increasing number of flights since the June is peak season for school holidays.

Moreover, it was also found that the reports on non-compliance procedures on the employees of PT. Gapura Angkasa of Minangkabau International Airport Padang occurred in the working unit of Cargo due to the lack of control on the cargo handover from warehouse to the shipper. It was evident from the number of occurred cases, where the numbers of registered cases in January were as many as 99 cases. The same thing also happened in February with 121 cases, in March with 115 cases, in April with 127 cases, and in May with 137 cases. In June, the cases recorded were 146 cases. The highest number of cases occurred in June with the average of monthly cases reaching up to 58.4 cases.

The high number of these problems was assumed due to the low motivation of employees, as indicated with the phenomena of employees who are less motivated in performing a job, employees are less enthusiast, and lack of organizational support from employees in doing many tasks. This condition will result in a decrease in PT. Gapura Angkasa of Minangkabau International Airport Padang branch's employees' work performance and their failures to achieve targets set by the company.

Hasibuan (2005) mentions that the motivation process starts from unfulfilled needs. A person will find a way to fulfill those needs by working as an employee, who will be oriented towards one goal, which is to work well so that they could be paid each month to fulfill their needs. After working towards the goal, he will evaluate his work based on the result on how close he is in obtaining the goal and whether he is closer to his goal or not.

McClelland in Mangkunegara (2009) in his theory states that a person's performance is affected by the "mental virus" inside the person. A mental virus is a mental condition that drives a person to achieve maximum results. The mental virus is referred to as the need for achievement, the need for affiliation, and the need for power.

Based on the above opinion it is clearly indicated that the motivation has an effect on the employees' performance. If the employees have good motivation, it will then increase the company's performance and vice versa. Motivation, although it is not the only factor that affects performance, has a significant effect on work performance improvements.

Based on the described phenomenon, the hypotheses of this research are:

H1: The need for achievement has a positive and significant effect on the performance of employees of PT. Gapura Angkasa of Minangkabau International Airport Padang.

H2: The need for affiliation has a positive and significant effect on the employees' performance of PT. Gapura Angkasa of Minangkabau International Airport Padang. 
H3: The need for power has a positive and significant effect on the employees' performance of PT. Gapura Angkasa of Minangkabau International Airport Padang.

\section{Methods}

This study is causative research. According to Sugiyono (2005), a causative research is a study that states the relationship between cause and effect. This study describes the occurrence of facts and observes the effect of each independent variable $(X)$, consisting of needs for achievement, needs for affiliation and needs for power, on the dependent variable $(Y)$ in the form of the employees' performance. The sample of this study is all of the employees of PT. Gapura Angkasa of Minangkabau International Airport Padang, which amounts to 127 employees. To answer the research hypothesis, the technique of data analysis employed is multiple linear regressions with the use of SPSS Software version 24.0.

\section{Definition of Operational Variables}

The explanation of the variables of this study is shown in Table 1 below.

Table 1 Definition of Operational Research Variables

\begin{tabular}{|c|c|c|}
\hline Variable & Definitions & Indicator \\
\hline \multirow{6}{*}{$\begin{array}{l}\text { Performance } \\
\qquad(\mathrm{Y})\end{array}$} & \multirow{6}{*}{$\begin{array}{l}\text { A work result in which the } \\
\text { quality and quantity of the task } \\
\text { performed by an employee is in } \\
\text { accordance with the assigned } \\
\text { responsibilities. } \\
\text { Source: Mangkunegara (2011) }\end{array}$} & a) Quality of work \\
\hline & & b) Job Productivity \\
\hline & & c) Job-related knowledge \\
\hline & & d) Consistency (Reliability) \\
\hline & & e) Availability to perform works (Availability) \\
\hline & & f) Responsibility \\
\hline \multirow{3}{*}{$\begin{array}{l}\text { The Need for } \\
\text { Achievement } \\
\text { (X1) }\end{array}$} & \multirow{3}{*}{$\begin{array}{l}\text { Accomplishment of the related } \\
\text { behaviors as a result of a conflict } \\
\text { between expectations to succeed } \\
\text { and the fear to fail. } \\
\text { Source: Mangkunegara (2009:103) }\end{array}$} & a) Like to compete \\
\hline & & $\begin{array}{l}\text { b) Strong desire to achieve better working } \\
\text { result }\end{array}$ \\
\hline & & c) Effort to become an outstanding employee \\
\hline \multirow{4}{*}{$\begin{array}{l}\text { The Need for } \\
\text { Affiliation } \\
(X 2)\end{array}$} & \multirow{4}{*}{$\begin{array}{l}\text { A form of social contacts that } \\
\text { create a relationship or network. } \\
\text { Source: Mangkunegara (2009:103) }\end{array}$} & $\begin{array}{l}\text { a) Feeling proud when the work result is } \\
\text { appreciated }\end{array}$ \\
\hline & & b) Good teamwork with co-workers \\
\hline & & c) Like to perform collective job \\
\hline & & d) Have a good relationship with co-workers \\
\hline \multirow{5}{*}{$\begin{array}{l}\text { The Need for } \\
\text { Power (X3) }\end{array}$} & \multirow{5}{*}{$\begin{array}{l}\text { Influences and seeks } \\
\text { improvement as a part of the } \\
\text { objectives of behavior that result } \\
\text { in the needs for achievement. } \\
\text { Source: Mangkunegara (2009:103) }\end{array}$} & a) Like to be the one in charge \\
\hline & & $\begin{array}{l}\text { b) Have the ability to influence peers in } \\
\text { performing job }\end{array}$ \\
\hline & & c) Like to be involved in decision-making \\
\hline & & d) Aspire to become a leader \\
\hline & & $\begin{array}{l}\text { e) Work with high expectation to achieve a } \\
\text { certain position }\end{array}$ \\
\hline
\end{tabular}

\section{Results and Discussion}

\section{Multiple Linear Regressions}

To find out the value of regression coefficient for each independent variable and the direction of the effect on the dependent variable, the result of multiple regression analysis using SPSS software version 24 on the obtained data is shown as follows: 
Table 2 Results of Multiple Regression on Research Variables

\begin{tabular}{cllllll}
\hline \multirow{2}{*}{ Model } & \multicolumn{2}{c}{$\begin{array}{c}\text { Unstandardized } \\
\text { Coefficients }\end{array}$} & $\begin{array}{c}\text { Standardized } \\
\text { Coefficients }\end{array}$ & \multirow{2}{*}{$\mathrm{t}$} & \multirow{2}{*}{ Sig. } \\
\cline { 3 - 5 } & & $\mathrm{B}$ & Std. Error & Beta & & \\
\hline \multirow{2}{*}{1} & (Constant) & 0.339 & 0.223 & & 1.521 & .131 \\
\cline { 2 - 6 } & Achievement & 0.200 & 0.084 & 0.202 & 2.375 & .019 \\
\cline { 2 - 6 } & Affiliation & 0.153 & 0.114 & 0.148 & 1.339 & .183 \\
\cline { 2 - 5 } & Power & 0.525 & 0.097 & 0.539 & 5.442 & .000 \\
\hline
\end{tabular}

a. Dependent Variable: Performance

Source: Result of Primary Data Processing (2018)

Based on the results of regression from Table 2 above, the equation for multiple linear regressions in this study is determined as:

$Y=0.339+0.200 X_{1}+0.153 X_{2}+0.525 X_{3}$

Note:

$\mathrm{Y}$ : Performance

$X_{1:}$ Need for Achievement

$X_{2}$ : Need for Affiliation

$X_{3}$ : Need for Power

The interpretation of the obtained regression equation is:

1) The constant value of 0.339 with a positive sign means that without employee motivation in the form of the need for achievement, need for affiliation, and need for power in performing their job, the employees still show a positive performance.

2) The regression coefficient of the need for achievement (X1) is 0.200 and it is positive. This indicates that the high need for achievement of the employees will also increase the employees' work performance.

3) The regression coefficient of the need for affiliation (X2) is 0.153 and it is positive, which indicates that the high need for affiliation in the employee will also increase the employees' work performance.

4) The regression coefficient of the need for power (X3) is 0.525 and it is positive, which indicates that the high need for power of the employees will also increase the employee's work performance.

\section{Hypothesis Test (t-test)}

The t-test was conducted to find out whether the hypotheses made by the author are acceptable or not, as indicated by the significance value of the coefficient seen in Table 2 above. The t-test results for each independent variable on the dependent variable are explained as follows:

1. The need for achievement (X1) has a significant effect on the performance $(Y)$ of employees of PT. Gapura Angkasa of Minangkabau International Airport Padang. The obtained sig. value is $0.019<0.05$, which means that $\mathrm{H} 0$ is rejected and Ha is accepted. It is concluded that the need for achievement has a significant effect on employees' performance.

2. The need for affiliation (X2) does not significantly affect the performance $(\mathrm{Y})$ of the employees of PT. Gapura Angkasa of Minangkabau International Airport Padang. The obtained sig. value is $0,183>0,05$ which means that Ha rejected and H0 is accepted. Thus, the need for affiliation has no significant effect on employees' performance.

3. The need for power (X3) has a significant effect on the performance $(\mathrm{Y})$ of the employees of PT. Gapura Angkasa of Minangkabau International Airport Padang. The obtained sig. value is 
$0.000<0.05$ which means that $\mathrm{H} 0$ is refused and Ha is accepted. Thus, the need for power has a significant effect on employees' performance.

\section{Coefficient of Determination}

To find out the effect of the independent variables, which consist of the job motivation dimensions (need for achievement, need for affiliation, and need for power), on employees' performance of PT. Gapura Angkasa of Minangkabau International Airport Padang, the effect is seen in the value of adjusted R square shown in Table 4.

\begin{tabular}{|c|c|c|c|c|}
\hline \multicolumn{5}{|c|}{ Table 3 Model Summary } \\
\hline Model & $\mathrm{R}$ & R Square & $\begin{array}{l}\text { Adjusted } \\
\text { R Square }\end{array}$ & Std. Error of the Estimate \\
\hline 1 & $0.827 \mathrm{a}$ & 0.683 & 0.675 & 0.48645 \\
\hline \multicolumn{5}{|c|}{ a. Predictors: (Constant), Power, Achievement, Affiliation } \\
\hline \multicolumn{5}{|c|}{ b. Dependent Variable: Performance } \\
\hline
\end{tabular}

The value of adjusted $\mathrm{R}$ square is 0.675 , which indicates that the contribution of the independent variable on the dependent variable is $67.5 \%$, whereas the rest $32.5 \%$ is determined by other factors not examined in this research.

\section{Discussion}

First Hypothesis (The Effect of the Need for Achievement on Performance)

The need for achievement has a partial significance on the employees' performance. This indicates that the demands and targets should be met by the employees of PT. Gapura Angkasa of Minangkabau International Airport Padang will affect the motivation of the employees. This, in turn, will drive the employees to be creative in accomplishing satisfactory achievement. Employees are required to come up with new ideas in their jobs. The needs for achievement will encourage employees to bring out their optimal capabilities in the form of creative ideas, mental or physical strength to work hard, the ability to think independently, and perseverance. The employees of PT. Gapura Angkasa of Minangkabau International Airport Padang could also find solutions to their problems and receive fast feedback on their performance. This will help them to know whether they are doing their best or not, and they could achieve challenging goals and contribute to the development and delivery of new ideas so that their potentials could develop well. The high achievers also prefer situations where their achievements are due to their own efforts and not by other factors such as luck. The result of this study is in line with the research conducted by Adim, Mochammad, and Yuniadi (2015), who also concluded that the need for achievement has a significant effect on performance.

\section{Second Hypothesis (The Effect of the Need for Affiliation on Performance)}

The result of this research showed that the need for affiliation variable obtained the regression coefficient of 0.153 , which means that the coefficient is of positive value. This means that an increase in the variable of the need for affiliation will increase the variable of employee performance, and vice versa. The variable of the need for affiliations does not significantly affect the variable of employees' performance. Although employees have the desire to become the best employee by performing the job on-time and satisfactorily and gain appreciation from the leaders and co-workers, they do not like the excessive appreciation. This is because they think that appreciation will result in an atmosphere of competition, and it will create uncomfortable situation while they are performing collective work. Competition might lead to the frequent occurrence of work conflicts that affect the collaboration among employees, which in turn will have an impact on a decrease in employees' performance. The 
result of this study is in line with research conducted by Zulfitri (2016), who also concluded that the need for affiliation has an insignificant effect on performance.

\section{Third Hypothesis (The Effect of the Need for Power on Performance)}

The need for power has a partial significant effect on the variable of employees' performance. The need for power is the driving force that stimulates employees to direct all of their abilities in order to achieve the best position or influence. Employees who have the work motives in the form of a high need for power will enjoy being burdened, will strive to influence others, prefer to be placed in a competitive and a status-oriented condition, and tend to be more concerned on prestige and gaining influence on others than on the purpose of effective performance. The result of this study is not in line with research conducted by Adim, Mochammad, and Yuniadi (2015), who concluded that the need for power has no significant effect on performance.

\section{Conclusions}

Based on the results and discussion, the conclusions of this study are:

1. Employees' motivation in the form of the need for achievement has a positive and significant impact on the performance of the employees of PT. Gapura Angkasa of Minangkabau International Airport Padang because the employees in general always try to perform their work well, on time and satisfactorily.

2. Employees' motivation in the form of the need for affiliation has a positive and insignificant effect on the performance of the employees of PT. Gapura Angkasa of Minangkabau International Airport Padang because the employees feel that the job will become easier if it is performed collectively. However, working collectively could result in a competitive feeling, so it has no impact on improving employees' performance.

3. Employees' motivation in the form of the need for power has a positive and significant effect on the performance of employees of PT Gapura Angkasa of Minangkabau International Airport Padang Branch because the need for power is the driving force that stimulates employees to direct all of their ability to achieve the best position or influence.

\section{Acknowledgments}

We would like to thanks to Department of Management, Sekolah Tinggi Ilmu Ekonomi Perdagangan which has funded this research and all those involved in the completion of the research.

\section{References}

Adim, I. D., Mochammad, D. M., \& Yuniadi, M. (2015). Pengaruh kebutuhan prestasi, kekuasaan, dan afiliasi terhadap kinerja karyawan. Jurnal Administrasi Bisnis (JAB), 24 (2).

Dessler, G. (2010). Manajemen Sumber Daya Manusia. Jakarta : Salemba Empat

Griffin, R. W., \& Ebert, R. J. (2002). Bisnis. Jakarta : Prenhallindo.

Hasibuan, M. S.P. (2005). Manajemen Sumber Daya Manusia, Edisi Revisi. Bumi Aksara, Jakarta

Hudiwinarsih, G. (2005). Pengaruh pengalaman auditor intern bank terhadap profesionalisme dan keterkaitannya dengan kinerja, kepuasan kerja, komitmen, dan turnover intentions. Jurnal Ventura, Vol 8, No 1.

Kamus Besar Bahasa Indonesia

Mangkunegara, A. P. (2009). Manajemen Sumber Daya Manusia Perusahaan. Jakarta: PT. Remaja Rosdakarya.

Mangkunegara, A. P. (2011). Manajemen Sumber Daya Manusia Perusahaan. PT. Remaja Rosda Karya, Bandung

Nindyati, A. D. (2014). Sex role identity dan self efficacy sebagai mediator hubungan tiga kebutuhan menurut mcclelland dengan kinerja beauty advisor pt. X di jakarta. Retrieved January 10, 2018 
from http://www.academia.edu

PT. Gapura Angkasa. (2016). Laporan Ketidaksesuaian Prosedur Pada Karyawan PT. Gapura Angkasa Bandar Udara Internasional Minangkabau Cabang Padang Periode Januari sampai dengan Juni 2016. PT. Gapura Angkasa Bandar Udara Internasional Minangkabau Cabang Padang.

Rivai, V., \& Sagala, E. J. (2009). Manajemen Sumber Daya Manusia untuk Perusahaan. Jakarta: Rajagrafindo Persada

Sugiyono. (2005). Metode Penelitian Bisnis. Bandung: Alfabeta.

Sunyoto, D. (2015). Manajemen dan Pengembangan Sumber Daya Manusia. Penerbit: CAPS, Yogyakarta.

Zulfitri. (2016). Pengaruh kebutuhan berprestasi, berafiliasi, kekuasaan, dan kemampuan terhadap kinerja pekerja pada bri cabang pekanbaru tuanku tambusai. KURS, 1(1). 